\title{
Planning and Design Principles of Transmission Line in Water Supply Project
}

\author{
Necati Gulbahar*: \\ *Department of Civil Engineering, Faculty of Engineering and Architecture, Istanbul Gelisim University, Istanbul, Turkey. \\ (ngulbahar@gelisim.edu.tr )
}

${ }^{\star}$ Corresponding Author; Necati Gulbahar, Department of Civil Engineering, Faculty of Engineering and Architecture, Istanbul Gelisim University, Istanbul, Turkey, Tel: +90 212422 7020, Fax: +90 212422 7401, ngulbahar@ gelisim.edu.tr

Received: 11.03.2016 Accepted: 18.03.2016

\begin{abstract}
Water is an essential substance for human life and living things. It is not substance for the life, but also energy input for agricultural and industrial production. In addition to, it is needed for human daily activities and environment. Water is taken to a place where people need by with transmission lines in water supply project. A transmission line is designed according to requirements, topographic conditions, engineering principles and economic criteria. Transmission lines are large scale projects which planned and projected by public organizations which are DSI, Provincial Bank and Municipalities. Although they are competent and experienced; some problems have been observed in water supply projects such as; lack of future plan, expropriation problem, improper pumping station, incapacity, inefficiency, pollution, poor quality, necessity, inadequate itineraries, too long lines. To avoid these problems, first future development plan for cities should be made and carried out without compromising. Next, the detail study should be carried out for each project from engineering, environmental and economic aspects. In this paper, these issues were examined and discussed to take attention to some important points in planning and designing of transmission line for the application.
\end{abstract}

Keywords: Transmission, water supply, planning, design.

\section{Introduction}

Water is the basic material for humans and other living things they need for survival of them. Besides, water is a source of energy that people need, at the same time, it is an essential input for agriculture and industry. Furthermore, water is a determining component of environment. These issues emphasize the importance of water that cannot be discussed. However, the determining factors of policies of societies in history can be listed as water, food and energy.

In the history, the aqueducts instructed by Romans are a transmission line in terms of engineering in Istanbul. Water requirement of Istanbul was supplied from water resources in Belgrade Forest which is $33 \mathrm{~km}$ from the city.

Presently, the water requirement of Istanbul is supplied from Melen Dam on the Melen River in Duzce Province with Melen transmission line which is $185 \mathrm{~km}$ length and with the diameter 2540-3000 $\mathrm{mm}$. The project having four stages and will supply totally $34.2 \mathrm{~m}^{3} / \mathrm{s}$ discharge until the year 2040 . (Fig. 1)

Similarly, the water requirement of Ankara is supplied with a transmission line from Kesikkopru Dam which is 128 $\mathrm{km}$ length with the diameter1400-1600mm Steel CTP pipe.
Another transmission line, water conveyed Alakopru Dam in Anamur from Turkey to the Gecitkoy Dam in Turkish Republic of Northern Cyprus (TRNC). The transmission line which is the first in the world covers four stages which are Turkey coast, sea crossing, TRNC coast and country network. It is totaly $106 \mathrm{~km}$ length with the diameter of $1600 \mathrm{~mm}$ high density polyethylene pipe with the discharge $2.38 \mathrm{~m}^{3} / \mathrm{s}$. (Fig. 2-Fig. 3).

The need of society is increasing day by day due to population growth and technological advances as a result of these natural resources are rapidly consumed. Worse, resources have been polluted which contributes to the amount of reduction. Actually, water resources are a concrete sample for this situation.

A transmission line is a line which is transmitting to take water from a source where needed in any water supply projects. There is no water distribution from this line. If this line fails for any reason, the area will not be supplied. Therefore, the double or triple line should be constructed according to needs. In order to transport water from long distances safely, transmission lines should be constructed in accordance with engineering, environmental and economic criteria. Transmission line is not only used water, but also oil 
and gas. As compared with other forms of transport, transmission line is much safer and cheaper than all of types transport.

Transmission lines are mainly constructed in two ways which are free surface and pressure systems due to topographical, engineering and economic reasons. If resource is higher than the reservoir, transmission is designed under gravity. Otherwise, pumping is needed. There are several types of free surface transmission systems. It is preferred the optimum type according to topographic and economic conditions. The transmission line can be classified as follows;

a. Free surface systems

- Open channel

- Aqueduct

- Tunnel

- Galleries

b. Pressurized systems

- Gravity

- Pumping

- Gravity-pumping

In this paper, a transmission line as a part of water supply project will be discussed and some important points will be emphasized for the purpose of better design in the application.

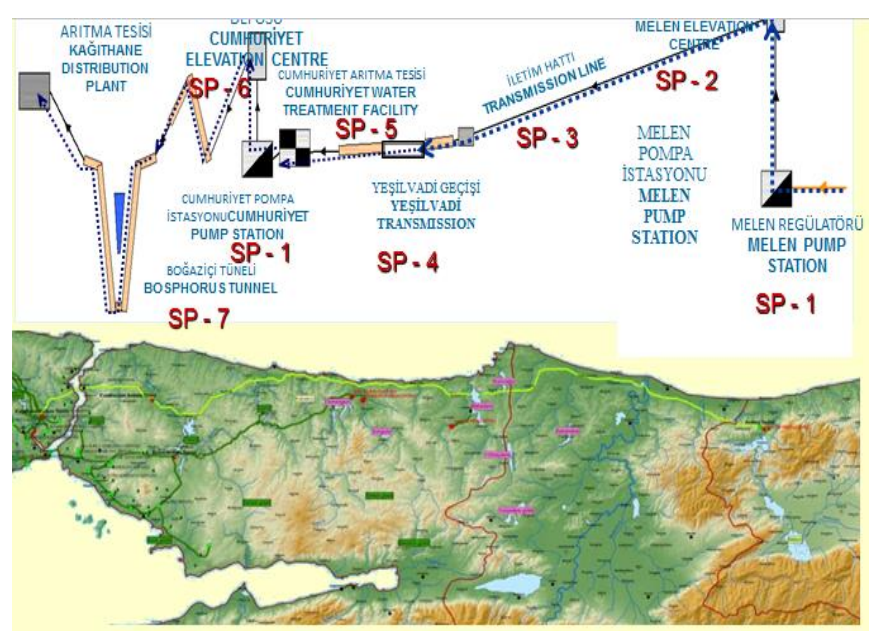

Fig. 1. Melen project plan and transmission line [2]

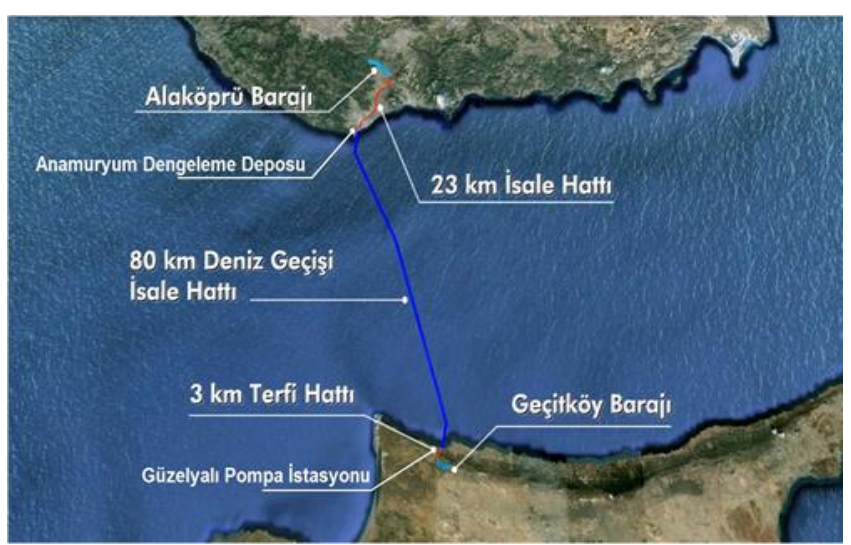

Fig. 2. Plan of transmission line between Turkey and TRNC [6]

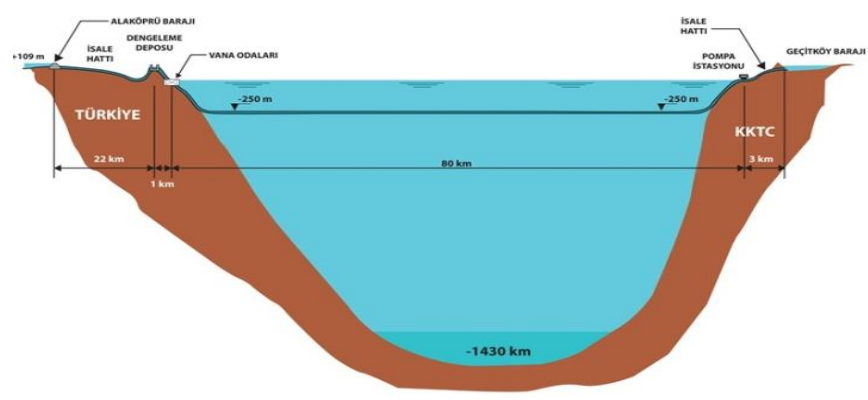

Fig. 3. Profile of the transmission line between Turkey and TRNC [6]

\section{Design principle of transmission line}

Mainly, transmission lines have been designed in two ways which are gravity and pumping systems. Gravity Systems, The most important point in this method is to determine piezometric line carefully. The piezometric line is indicated as $\mathbf{P} / \gamma+\mathbf{z}$ which are pressure head and geometric elevation that is provided with the difference between the static line and the pipe. In case of water resource is at the higher elevation than the storage reservoir in the city, the water can convey by the gravity. First an itinerary is determined next ground and pipe profile is designed. Then pipe diameter is determined based on piezometric line and discharge. Head loss should not be bigger than piezometric head which is the difference between piezometric line and pipe level.

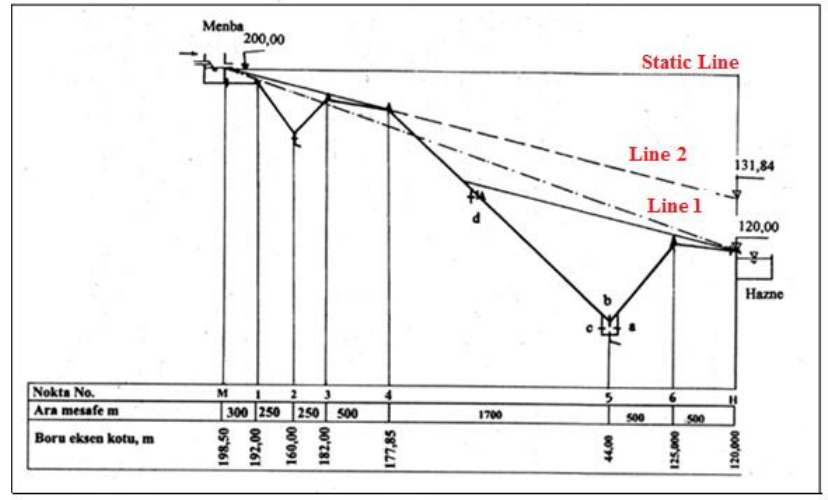

Fig. 4. Gravity transmission line designed by classical method [10]

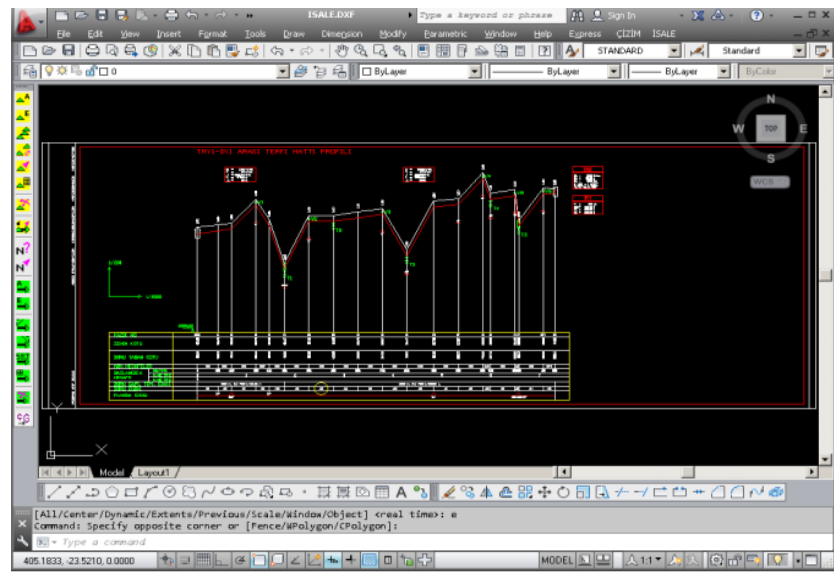

Fig 5. Transmission line designed by computer [4] 
From the Figure 4, Line 1 is not acceptable due to pressure decrease or free water surface occurs, but Line 2 is acceptable because operating pressure is at designed level, which can be easily adjusted by valve.

In a pumping System, determining of the manometric head is the most important part that the pump gives energy to water by converting mechanical energy to hydraulic energy. Manometric height must cover all of head losses and difference in geometric elevation between resource and reservoir including efficiency of pump and motor.

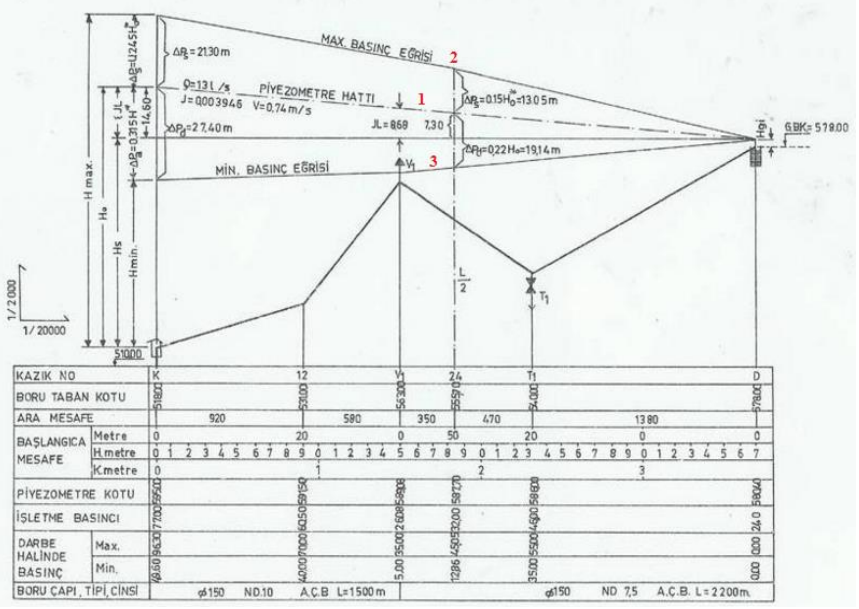

Fig. 6. Transmission line by pumping with classical method [12]

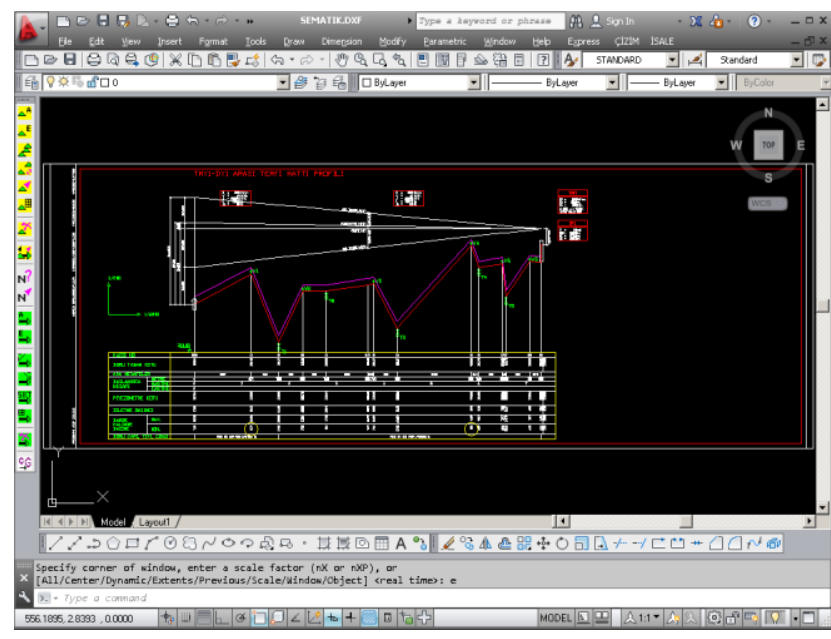

Fig. 7. Suppression and depression calculated by computer [4]

Suppression and depression pressure occur which damage to pipe system in a pumping and it must be calculated. In case of energy cut off, water mass in the pipe first stops, then flows with the high velocity to the pump. This is called as water hammer. At the same time, behind the water mass in the pipe creates a suction which is called depression. This event may also occur more slightly when valve is suddenly closed According to physical conditions, air tank capacity should be calculated and put in the system for reducing the over pressure. Pumps are connected to each other parallel and series with reference to the requirements and conditions. Generally, besides operating pumps, one of them is kept as a spare or stand-by. (Fig. 8).

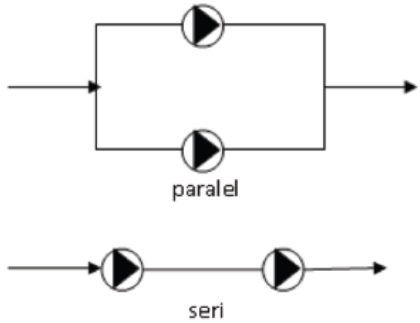

Fig 8. Series and parallel connections [7]

Transmission lines may have curve in some parts of lines. This is applicable with flexible material easily. However some formulas may be used for calculation of minimum radius of curve. Although, $1 \mathrm{~m}$ depth soil may be eliminated harmful effect of external forces, this can be identified by various formulas.

\section{The elements of a sustainable water supply and sewage systems}

The basic requirement of sustainable water resource management is that water is taken from nature and given back to nature at least with the same quality with reference to Bruntland report. Therefore, it should be considered as a whole to water supply and sewage system design in any project. Such a system is given in the following schematic layout. (Fig. 9).

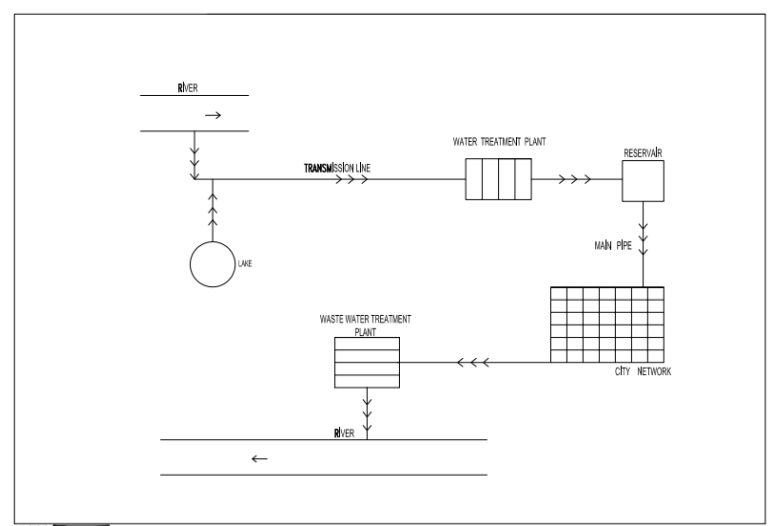

Fig. 9. A sustainable water supply system

From the Figure 9, first surface and underground water resources are collected and transmitted to water treatment plant with the transmission line by means of pumping. After the treatment, it is conveyed to reservoir with transmission line. Next, water is taken from reservoir to the city network with the main pipe. Finally, the outflow water from the network is defined as waste water which should be conducted to the river after treatment process.

\section{Points to be considered for planning transmission line}

In Turkey legally, authorized government agencies regarding water supply and sewage system are DSI, Iller Bank and municipalities. These institutions carry out planning and designing works of infrastructures in cities and rural areas according to the technical regulations which have developed by their institution. The technical regulations of 
DSI will be based on here. Some important items for necessary in designing of transmission line according to the Technical Regulations of Drinkable Water of DSI are summarized as follows;

- Transmission lines should be the shortest line having the highest elevation as possible

- Transportation should be easy and necessary structures must be less

- Flood and landslide risk should be less and far from the river bed

- Pipe diameter selection will be done by 35 years of economic analysis and discharge at that time

- Plans will be the $1 / 1000$ and $1 / 2000$ and the profiles $1 / 200$ and $1 / 100$

- Polygon points, some points and angles will be shown.

- The distance and intermediate distances will be displayed in plan and profile

- The calculation of control and measuring structures will be made separately

- Pressure will be broken with structures if hydraulically is possible

- Air accumulated at peak point in the line will be evacuated with chimney if possible

- Water discharging valve will be put at the lowest point in the line

- Trench depth will be $1 \mathrm{~m}$ up to $2000 \mathrm{~mm}$ and over 2000 it is $1.25 \mathrm{~m}$

- The anchoring block will be constructed for stability at sloping areas

- Preventive measures will be taken at the landslide areas

- The pipe will be run under the pressure given by the factory for safety

- Calculations will be made based on static pressure for systems operating with gravity

Except mentioned above, some additional points given at the following that is thought to be useful

- Velocity of water should be $\mathrm{V}_{\text {min }}=0.5 \mathrm{~m} / \mathrm{s}$ and $\mathrm{V}_{\text {Max }}=$ $3 \mathrm{~m} / \mathrm{s}$ for pipes and $\mathrm{V}_{\min }=0.5 \mathrm{~m} / \mathrm{s}$ and $\mathrm{V}_{\mathrm{Max}}=2 \mathrm{~m} / \mathrm{s}$ for open channel.

- Cost of drinkable water and waste water treatment systems should be included to the total costs

- Calculations of water needs should be made according to the Provinces Bank method

- Gravity system should be preferred even though expensive by $25 \%$

- Operating Pressure must be $\mathrm{p}_{\min }=30 \mathrm{~m}$ and $\mathrm{P}_{\max }=80 \mathrm{~m}$
- At sloping land for uphill elevation will be 0.002 and down-hill elevation will be 0.005

- The cost of $1 \mathrm{~m}^{3}$ of water should be determined at the end of this calculation

\section{Works for transmission line projects}

In a water supply project, besides hydrologic and hydraulic study, some certain studies related to construction such as excavation, filling, formwork, concrete, all kinds of work, are available. These are gradual work that each stage is a continuation of the previous stage. Works are known at schedule when and how to do is going to be done. However, the only transmission line works were examined in this paper.

According to technical regulations of the drinking water of DSI, the following works related to the transmission line should be carried out and be prepared in a computer;

- General layout

- Transmission line plan

- Transmission line profile

- Schematic profile of transmission line

- Catchment project (Plan, Profile, Formwork Plan)

- Preservation area project

- River gateway, anchoring block, preservative wall

- Energy transmission line project

According to the above mentioned Regulation of DSI, depending on the gravity or pumping transmission, the following calculations must be done;

- Hydrologic calculations

- Hydraulic calculations

- Moto-pump calculations

- Anchoring block calculations

- Static and reinforced concrete calculations

- Suppression, depression, air boiler calculations

- Bill of Quantities for only engineering structures

- Structures of measuring and control

- Bill of Quantities (BOQ)

- Calculations for other works

Additionally, it is suitable to add to the calculation the following items;

- Excavation-Filling

- Traffic load 


\section{Equations used for hydraulic calculation}

Mainly, continuous head loss and local loss calculation should be made in transmission line. Calculation for the engineering structures should be considered as the local loss and added to it.

For the gravity pipelines, Continuity, William-Hazen, Darcy-Weisbach equations or Moody diagram can be used. In pumped line, pump power, suppression, depression and air boiler capacity must be calculated separately. For open channel, Manning and Darcy-Weisbach equations can be used. Important formulas for hydraulic calculations are given at the following;

$$
\begin{array}{ll}
\text { William-Hazen } & : \mathrm{V}=0.85 \cdot \mathrm{C} \cdot \mathrm{R}^{2.63} \cdot \mathrm{J}^{0.54} \\
\text { Continuity } & : \mathrm{Q}=\mathrm{A} \cdot \mathrm{V} \\
\text { Local loss } & : \quad \mathrm{h}_{\mathrm{ky}}=\mathrm{k} \cdot \frac{v^{2}}{2 g}
\end{array}
$$$$
\text { Power of the pump : } \quad \mathrm{N}_{\mathrm{p}}=\frac{\gamma \cdot Q \cdot H_{m}}{75 . \eta}
$$$$
\text { Manning } \quad: \quad \mathrm{V}=\frac{1}{n} \mathrm{R}^{2 / 3} \mathrm{~S}^{1 / 2}
$$$$
\text { Darcy-Weisbach } \quad: \quad \mathrm{h}_{\mathrm{k}}=\mathrm{f} * \frac{l}{d} * \frac{v^{2}}{2 g}
$$$$
\text { Pressure wave speed } \quad: \quad a=\frac{9900}{\sqrt{49+k+\frac{D}{\Sigma}}}
$$$$
\text { Süpression - Depression : } \Delta \mathrm{H}= \pm \frac{\mathrm{V} \bullet V}{g}
$$

Curve radius

$$
\mathrm{R}=\frac{L / 2}{\sin \frac{\alpha}{2}}
$$

External force acting pipe : $\mathrm{W}=\gamma_{\mathrm{t}} \cdot \mathrm{H}$

$$
\text { Bresse } \quad: \mathrm{D}_{\mathrm{e}}=1.5 \sqrt{Q}
$$

Where;

$\mathrm{N}_{\mathrm{p}}$ : power

$\gamma:$ Specific wight of water

Q: Discharge

C: coefficent

$\mathrm{H}_{\mathrm{m}}$ : Manometric height

$\eta_{\mathrm{p}}$; pump efficiency

$\eta_{\mathrm{m}} ;$ motor efficiency v: velocity

f: coefficient friction

1: lenght

d ,D: diameter

$\mathrm{n}$ : ruffness coefficient

$\mathrm{R}$; hydraulic radius

$\mathrm{S}, \mathrm{J}$ : land slope

hk: frictional loss

a: velocity of pressure wave

$\Delta \mathrm{H}$ : head loss

A; cros sectional area

$\mathrm{k}$ : coefficient

$\mathrm{k}_{\mathrm{m}}=$ coefficent of material

$\mathrm{g}=$ gravitational acceleration

$\mathrm{e}=$ material thickness

$\mathrm{R}$ : Minimum radius of curve

$\alpha=$ central angle of curve

$\mathrm{L}=$ length on the curve between two points

$\mathrm{W}=$ soil pressure

$\gamma_{t=}$ specific weight of soil

$\mathrm{D}_{\mathrm{e}}=$ economic diameter

$\mathrm{H}=$ excavation depth

\section{Engineering structures in transmission line}

Various structures have been used in transmission lines with reference to necessity which are trough, air valve, drain valve, surge tank, air boiler, anchored block, pumping station and special constructions that are briefly summarized below;

- Trough: It is made to reduce the pressure. Water inflows to it, and outflows under the gravity force.

- Air valve: It is used at the top points of the line for evacuation air when the pressure in the pipe decreases.

- Drain valve: It is placed at lowest points of the line and used to drain the water when needed

- Surge tank: It is used for preventing pumping pressure fluctuations occurring in the pipe line.

- Anchored block: It is placed when pipeline passes through on slope areas or dynamic forces in the elbow of pipe to prevent separation from the ground.

- Pumping stations: It provides energy to water. It is needed when the pipe lines which is not run under the gravity. 
- Water treatment plant; It is needed to improve water quality with reference to drinkable water standards.

- Special construction: It is needed when the pipe pass through such as; swamp, lake, river and sea.

\section{Pipe material}

In order to select pipe material, various factors have been considered such as; chemical properties of water, properties of the alignment, strength, lifetime and economic criteria are considered. Determining pipe material thickness, the operating pressure, external pressure, and water impacts should be taken into account. Pipes have been made from different materials such as; steel, cast 1ron, ductile, poly ethylene (PE), poly vinyl chloride (PVC), glass fiber reinforced pipe (CTP) and concrete. Specifications of these materials are briefly given as follows (Karadogan, 2010):

Steel: High strength, fracture-proof, lightweight and economic but it needs a protective coating.

Cast Iron: Corrosion-resistant, medium strength, durable, more thickness, heavy, fragile against impact

Ductile: High strength, less fragile but imported material

PVC and PE: Strength good, not economic in large-scale, PE flexible but PVC non-flexible.

CTP: Composites pipes that are made using non-metallic chemical substance. Good strength, corrosion resistance but not economical

Concrete: less strength, fragile for impact and heavy

\section{Economy of transmission line}

Identifying of the optimum diameter in a transmission line is very important. If it is taken the great diameter, the cost of the line increases in that case head losses is reduced. If small diameter is selected, the cost of the line decreases, but this time head losses increases that increases energy cost of the motor and pump power. This situation is shown at the following schematic graph in Fig. 10. From the figure, the number 1 shows annual expenses, the 2 is related to construction cost, the 3 shows the total cost. The optimum point is at $D_{\mathrm{e}}$. However, at the planning stage Bresse formula can be also used for the estimation of economical diameter.

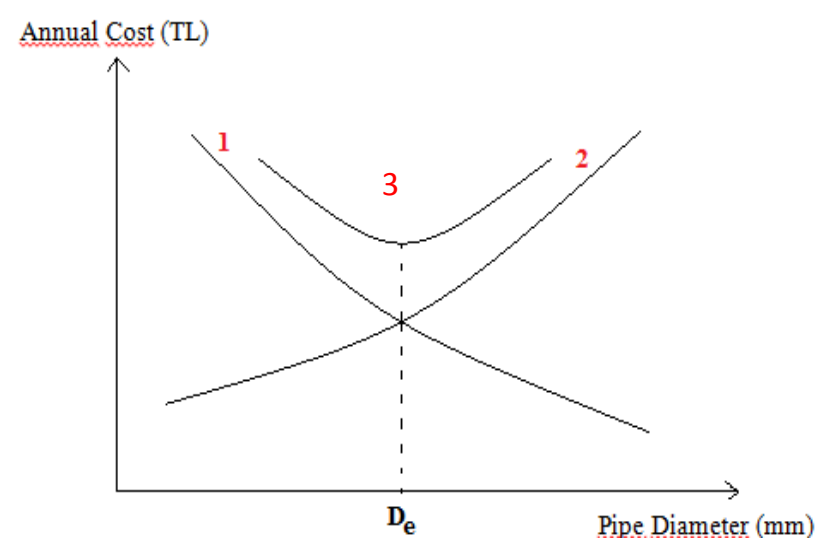

Fig. 10. Economic diameter of pipe [11]

\section{Conclusion}

As explained above; the most important part of a water supply projects is transmission line. A transmission line may be pipe line or open channel which conveys water to treatment plant. Usually, for drinkable water transmission has been designed due to pollutions and evaporation loss problems. Generally, although gravity system is preferred the topographical conditions are not adequate to convey the water by gravity. Therefore, pumps must be used for energy provide. Another important point, a number of distribution storage reservoirs must be designed to meet hourly variation demand of water depending pressure conditions. Because of the failure of the transmission line for any reason, the line which feeds the area will not have water. It means an interval of social life. Therefore, the place where the line passed through the topography and soil conditions of land should be well studied and itinerary well determined. Likewise, calculations of pipe diameter to meet future requirements are also important. Transmission lines should be as short as possible, which requires less structure and should go up and down with the suitable slope. If possible, it should not be passed through river beds, the marshland and lake. However, if transition is necessary for passing through like these places, then specific projects must be prepared as required. Transmission lines in terms of security must be planned as a double line. From the sustainable view point, the line should not damage to environment and ecological balance should not be disturbed especially during construction and operation period. Finally, the line should be acceptable from economic view point.

\section{References}

[1] DSI, İçme suları Genel Teknik Şartnamesi, DSI Matbaas1, Ankara.

[2] DSI Directorate of $14^{\text {th }}$ District, Istanbul Great Drinking Water Supply Project Stage II Documentation, 2011, Istanbul.

[3] Giles V.R. Teori ve Problemlerle Akışkanlar Mekaniği, Scaum's Outline Series, Mc Grow Hill Company, 1976.

[4] http://www.ankisoft.com.tr/ [Online]

[5] http://www.cmo.org.tr/ [Online]

[6] http://www.dsi.gov.tr/ [Online]

[7] Karadogan H., Boru Hatları Tasarımı, 2010.

[8] Karpuzcu M., Su Temini ve Çevre Sağlığı, Kubbealti Nesriyati, İstanbul.

[9] Muslu Y., Çözümlü Problemlerle Su Temini ve Çevre Sağlığı, Su Vakfı Yayınları, 2005, İstanbul.

[10] Muslu Y., Su ve Atık Su Teknolojisi, Seç Yayınevi, 2000, İstanbul.

[11] Sa Marques J.A. and Oliviera J.J., Hidraulica Urbana, Universida de Coimbra, 2011. 
INTERNATIONAL JOURNAL Of ENGINEERING TECHNOLOGIES

Necati Gulbahar, Vol.2, No.1, 2016

[12] Samsunlu A., Su Getirme ve Kanalizasyon Yapılarını Projelendirilmesi, SAM Çevre Teknolojileri Merkezi, 1997, İstanbul.

[13] Sogukoglu M., Akışkanlar Mekaniği ve Çözümlü Problemler, Birsen Yayinevi, 2010, Istanbul.

[14] Sumer M., Unsal I. and Bayazit M., Hidrolik, Birsen Yayınevi, 2000, İstanbul.

[15] Turkdogan İ.F. ve Yetilmezsoy K., Su Getirme ve Kanalizasyon Uygulamaları, Su Vakfı Yayınları, 2004, İstanbul.

[16] Yanmaz A.M., Water Resources Engineering, METU Press, 2001, Ankara.

[17] Altinbilek H.D., Hydraulic Engineering with Solved Problems, METU, 1972, Ankara. 